\title{
Evaluation of Estridiol and Some Antioxidant in Breast Cancer Iraqi Women
}

\author{
Ghufran Saad Nsaif ${ }^{1 *}$, Amer Hassan Abdallah ${ }^{2}$, Najwa Shehab Ahmed ${ }^{3}$ and Wafaa Raji Alfatlawi ${ }^{4}$ \\ ${ }^{1,2}$ Chemistry department, College of Science, University of Al-Mustansiriyah, Baghdad-Iraq. \\ ${ }^{3}$ Biotechnology Research Center, University of Al-Nahrian, Baghdad-Iraq. \\ ${ }^{4}$ Applied Chemistry Branch, Applied Science department, University of Technology, Baghdad-Iraq. \\ Corresponding Author": saadalsaady19@gmail com.
}

\begin{abstract}
Cancer is the second reason of deaths worldwide while breast cancer is the more spread cancer in women, comprising $29 \%$ from all cancers that they are affected Samples were obtained from patients undergoing surgery in center from breast cancer in oncology teaching hospital Al-Eluia hospital for woman care All blood samples were taken of the patients (110 women) and divided into four groups benign, malignant, radiotherapy and control group In order to measurement estrogen levels which are influenced by the menstrual cycle, the main groups were furthermore divided into sub-groups, premenopausal and postmenopausal women The mean value \pm SE of Body Mass Index (BMI) for control, benign, malignant and radiotherapy breast cancer were showed a non-significant change in the comparison of groups according to the Duncan test Estrogen were increased before therapy but decreased following therapy The levels of malondialdehyde (MDA)were elevated in patients after radiotherapy The mean value \pm SE of vitamin $E$ were decreased in studied groups Present study aims to study the effects of serum estrogen, vitamin $\mathrm{E}$ and antioxidant status in breast cancer patients. [DOI: $10.22401 / \mathrm{JUNS} .21 .1 .06]$
\end{abstract}

Keywords: Estrogen, Vitamin E, MDA, BMI, Breast cancer

\section{Introduction}

Cancer is the second cause of mortality worldwide and breast cancer is the more prevalent cancer in women, comprising $29 \%$ of all cancers that they are influenced with It is as well worth mentioning that more than one million women are diagnose with breast cancer yearly According to statistics, the incidence rate of this disease is comparatively low in Asian and African countries, but it is increasing more rapidly in comparison with others countries [1]

Estrogens has major roles, it a key role in the progression from breast cancer obese women post menopause have estrogen and insulin Levels similar to growth factor tumors more than slim women post menopause [2] actually, surgery, radiotherapy, chemotherapy and hormone therapy are effectively used for the treatment from cancer patients radiotherapy, as one of usually used methods for the treating of cancer, is able to pull down remaining cancer cells after surgery Patients with cancer need radiotherapy either for curative or palliative purposes, however, this valuable method is associated with some major side effects [3]
Radiotherapy depend on reactive oxygen species(ROS)toxicity and can damage cellular macromolecules, such as DNA (deoxyribonucleic acid), RNA (ribonucleic acid), micro R-NAs, proteins and membrane in tumor cells Antioxidants protect normal cells against radiation injury through various enzymatic systems, such as catalase, superoxide dismutase It has been suggested that radiation can cause a decline in the level of vitamins $\mathrm{C}, \mathrm{E}, \mathrm{A}$ and selenium in breast cancer patients [4-6]

Free radicals have a role in carcinogenesis and the process includes three stages: initiation stage the change is permanent occurs in the genetic material, promotion stage expands of mutated cell clone and the last stage is progression which include the conversion of malignant to develops cancer ROS is a term that includes roots that focus on oxygen (Superoxide anion radical, Hydroxyl radical, Peroxyl radical, Lipid hydroperoxide, and Hydro peroxyl $\mathrm{HO}_{2}$ ) and DNA in cells and tissues, stimulate undesirable oxidation and causing membrane damage, protein modification, DNA damage, and cell death induced by DNA fragmentation and lipid peroxidation [7] 
Vitamin $\mathrm{E}$ is a fat-soluble vitamin The term of vitamin $E$ includes four tocopherols $(\alpha, \beta, \gamma, \delta)$ and four tocotrienols $(\alpha, \beta, \gamma, \delta)$, which are organic compounds that have different levels of antioxidant activity $\alpha$ Tocopherol molecular mass is $43071 \mathrm{Da}$ and, it is about a trimethylatedchromanol ring and a saturated phenyl side chain[8] $\alpha$-Tocopherol is the most effective form of vitamin $\mathrm{E}$ in humans, is a part of the antioxidant defense system[9]

MDA is one of the most common and a dependable marker to determine oxidative stress in clinical cases, therefore today's high reactivity and toxicity of this molecule is very important to biomedical research community [10]

Overweight or obesity are current escalating public health issues Near to one billion people worldwide are considered overweight (range of $25-290 \mathrm{~kg} / \mathrm{m}^{2}$ ), and as many as 475 million are plump (BMI $\geq 30$ $\mathrm{kg} / \mathrm{m}^{2}$ ) Furthermore, it is estimated that, by the year 2030, half of the world's population will be obese Over and, in developing countries, obesity is an established risk agent for many cancer and cancer related deaths [11]

\section{Methodology}

Samples were obtained from patients undergoing surgery in central of breast cancer in oncology teaching hospital and Al-Eluia hospital for woman care The complete physical examination was done to every patient All blood sample were taken of the patients (110 women) and divided into four groups as shown in Table (1):

Table (1)

Classification of individuals as main groups

\begin{tabular}{|c||c||c||}
\hline \hline Group & No & Age Range (year) \\
\hline \hline Control & 30 & $(30-59)$ \\
\hline \hline Benign & 30 & $(30-59)$ \\
\hline \hline Malignant & 30 & $(30-59)$ \\
\hline \hline Radiotherapy & 20 & $(30-59)$ \\
\hline
\end{tabular}

In order to measure estrogen levels which are affected by the menstrual cycle during the follicular phase, the master groups were further divided into sub-groups, pre and postmenopausal women as shown in Table (2):
Table (2)

Classification of individuals as sub-groups

\begin{tabular}{|c||c||c||c|}
\hline \multirow{2}{*}{ Main Group } & Sub-Group & No & $\begin{array}{c}\text { Age Range } \\
\text { (year) }\end{array}$ \\
\hline \hline \multirow{2}{*}{ Control } & Pre-menopause & 23 & $(30-59)$ \\
\cline { 2 - 4 } Benign & $\begin{array}{c}\text { Post- } \\
\text { menopause }\end{array}$ & 7 & $(30-59)$ \\
\cline { 2 - 4 } & $\begin{array}{c}\text { Pre-menopause } \\
\text { Pent- }\end{array}$ & 73 & $(30-59)$ \\
\hline \hline \multirow{2}{*}{ Malignant } & Pre-menopause & 23 & $(30-59)$ \\
\cline { 2 - 4 } & $\begin{array}{c}\text { Post- } \\
\text { menopause }\end{array}$ & 7 & $(30-59)$ \\
\hline \hline \multirow{2}{*}{ Radiotherapy } & Pre-menopause & 13 & $(30-59)$ \\
\cline { 2 - 4 } & $\begin{array}{c}\text { Post- } \\
\text { menopause }\end{array}$ & 7 & $(30-59)$ \\
\hline
\end{tabular}

- Hysterectomy surgery of women in age 30 years (post menopause).

The concentration of MDA in serum was determined according to Buege and Aust method enzymology (12) BMI was categorized into the following [13]:

1- BMI less than 185 (underweight)

2- BMI less than 249 (normal weight)

3- Between 25 - 299 (over weight)

Measurement of estradiol (E2) by EnzymeLinked Immune sorbent assay (ELISA) Method [14]Vitamin E were evaluatedby High performance liquid chromatography (HPLC) assay [15]

\section{Results and Discussion}

The high risk from breast cancer with an increased BMI after menopause is likely cause high levels of estrogen after menopause, fatty tissue becomes the most important source of estrogen instead of ovaries Women have more fatty tissues(obesity) therefore higher levels of estrogen and lead to the growth breast tumors [16]

The association of obesity with the risk of breast cancer is due to its association with metabolic syndrome, insulin resistance, and the formation of estrogen in the fatty tissues Obesity is known to be a risk factor for breast cancer and increasing risk post menopausal but not a pre-menopausal Obese women with high BMI have a higher risk of death than women lower BMI [17] There is some proof to suggest that, in women with a family history from breast cancer, weight gain significantly increases the danger of developed breast 
cancer compared with slimmer women with a family history[17] There are many hypotheses that explain the relationship between obese women post menopause and breast cancer:

1.The first hypothesis to link the obesity to the disease is the increase in estrogen for obese women post-menopausal in the circulatory system compared to slim women and the interruption of menstruation levels of hormone in circulation and in the fatty tissue

2.Obesity linked to metabolic syndrome, which is associated with the production of higher insulin, as well as insulin-like growth factor, which interferes with the estrogen receptors

3.A newer hypothesis places a dipocytes and their autocrine, paracrine, and endocrine functions at center stage This hypothesis sets forth that obesity should be considered an endocrine tumor a dipocytes, once

Table (3)

$\mathrm{BMI}\left(\mathrm{Kg} / \mathrm{m}^{2}\right)$ in control, benign, malignant and radiotherapy groups

\begin{tabular}{|c|c|c|c|c|c|c|}
\hline \multicolumn{3}{|c|}{ Parameters } & \multirow{2}{*}{$\begin{array}{c}\text { Cont } \\
N=30\end{array}$} & \multirow{2}{*}{$\begin{array}{c}\begin{array}{c}\text { Group } 1 \\
\text { Rad } \\
\boldsymbol{N}=\mathbf{2 0}\end{array} \\
21.3^{\text {ade }}\end{array}$} & \multirow{2}{*}{$\begin{array}{c}\begin{array}{c}\text { Group } 2 \\
\text { Mal } \\
N=30\end{array} \\
23.0^{\text {bdf }}\end{array}$} & \multirow{2}{*}{$\begin{array}{c}\begin{array}{c}\text { Group } 3 \\
\text { Ben } \\
N=30\end{array} \\
22.1^{\text {cef }}\end{array}$} \\
\hline \multirow{9}{*}{$\mathrm{BMI}\left(\mathrm{Kg} / \mathrm{m}^{2}\right)$} & \multirow{3}{*}{$\leq 24.9$} & Mean & & & & \\
\hline & & SE & 0.3 & 1.2 & 0.3 & 0.9 \\
\hline & & $\mathrm{No}$ & 7 & 9 & 5 & 4 \\
\hline & \multirow{3}{*}{$25-30$} & Mean & $27.5^{\mathrm{abc}}$ & $27.3^{\text {ade }}$ & $27.2^{\text {bdf }}$ & $27.8^{\mathrm{cef}}$ \\
\hline & & $\mathrm{SE}$ & 0.3 & 0.7 & 0.4 & 0.5 \\
\hline & & $\mathrm{No}$ & 15 & 6 & 13 & 14 \\
\hline & \multirow{3}{*}{$\geq 30$} & Mean & $35.1^{\mathrm{abc}}$ & $34.0^{\text {ade }}$ & $34.5^{\text {bdf }}$ & $36.3^{\mathrm{cef}}$ \\
\hline & & SE & 1.5 & 1.3 & 1.0 & 1.2 \\
\hline & & No & 8 & 5 & 12 & 12 \\
\hline
\end{tabular}

- Similar letters : Non-Significant difference $(P>0.05)$ between means.

- Different letters : Significant difference $(P \leq 0.05)$ between means.

MDA is an serious biological marker from lipid peroxide having the capacity to interact mainly with deoxyguanosine and deoxyadenosine DNA, which reasons mutations The formation of MDA leads to a decrease in plasma membrane fluidity and disruption of membrane enzymes and receptors and also disrupts calcium ion permeability [20] Many studies [21] have confirmed mutagenic of MDA property in humans, it promotes the development from several types of cancer, including breast, thought of as exclusively energy-storing cells, are dynamic endocrine cells and secrete various cytokines, polypeptides, and hormone-like molecules[18]

Despite the fact that estrogen has major roles, it plays a key role in the progression of breast cancer obese women post menopause have estrogen and insulin Levels similar to growth factor tumors more than slim women post menopause The effect of weight loss and the maintenance of a slim body in patients with breast cancer gives moderate results in risk reduction, therefore, obesity is considered to have an effect on the incidence of breast cancer is adjustable The effectiveness of drugs for breast cancer is either the closure of estrogen receptors in breast cells or inhibitors of aromatase enzymes [19] atherosclerosis and cardiovascular disease [22] The results show High $(\mathrm{P}<0.01)$ a significant increase between the four groups (benign, malignant, radiotherapy and control), as observed to a non-significant change $(p>0.05)$ when comparing between the control group and the malignant group.

This may be due to the fact that MDA depends on the size of the tumor and the spread of cytoplasmic less and is a type of tumor is weakly differentiated The presence of a rise MDA in cancer has been shown to be 
associated with the body's oxidative stress which leads to the loss of PUFA in the plasma membrane and asserts that oxidative stress lead to dysfunction in the mitochondria and even regulates important operators such as the nuclear respiratory agent In the case of radiation therapy, a significant increase was observed of MDA that radiotherapy increases the state of stress patients, increased MDA the result of exposure to radiation therapy [23]

\section{Table(4)}

MDA (mg/dl) in control, benign, malignant and radiotherapy groups

\begin{tabular}{|c|c|c|c|c|c|}
\hline \multirow{2}{*}{\multicolumn{2}{|c|}{ Parameters }} & \multicolumn{4}{|c|}{ Groups } \\
\hline & & \multirow{2}{*}{$\begin{array}{c}\text { Cont } \\
N=30\end{array}$} & \multirow{2}{*}{$\begin{array}{c}\text { Group } 1 \\
\text { Rad } \\
N=20 \\
8.7^{\text {bfh }}\end{array}$} & \multirow{2}{*}{\begin{tabular}{|c}
$\begin{array}{c}\text { Group 2 } \\
\text { Mal } \\
N=30\end{array}$ \\
$4.5^{\text {cgj }}$
\end{tabular}} & \multirow{2}{*}{\begin{tabular}{|c}
$\begin{array}{c}\text { Group 3 } \\
\text { Ben } \\
N=30\end{array}$ \\
$6.4^{\text {eik }}$
\end{tabular}} \\
\hline \multirow{2}{*}{$\begin{array}{l}\text { MDA } \\
(\mathrm{mg} / \mathrm{dl})\end{array}$} & Mean & & & & \\
\hline & SE & 0.43 & 0.7 & 0.6 & 0.8 \\
\hline
\end{tabular}

Table (5) shows the (Mean \pm SE) of Estradiol hormone in sera of control, malignant, benign and radiotherapy groups breast cancer depending on pre menopause and post menopause These results shows a nonsignificant change in estradiol levels $(p>0.05)$ in comparison of the pre-menopausal and postmenopausal control group with the benign, and radiotherapy groups, except for postmenopausal malignant group which shows significant elevation with others $(\mathrm{p}<0.05)$ In agreement with previous studies in Malaysia and Egypt [24,25] our study found increase E2 levels in pre-menopausal malignant breast tumor patients It was not statistically significant Also these results were convention with other previous studies that suggested a non-significant increase in mean E2 concentrations levels among pre-menopausal cases in comparison with controls [26]

Table (5)

Estradiol hormone (E2pg/ml) in sera of studied groups

\begin{tabular}{|c||c|c|c|c|c||}
\hline \multicolumn{1}{|c||}{} & \multicolumn{5}{c|}{ Groups } \\
\cline { 2 - 6 } Parameters & & $\begin{array}{c}\text { Cont } \\
\text { N=30 }\end{array}$ & $\begin{array}{c}\text { Group 1 } \\
\text { Rad } \\
\text { N=20 }\end{array}$ & $\begin{array}{c}\text { Group 2 } \\
\text { Mal } \\
\text { N=30 }\end{array}$ & $\begin{array}{c}\text { Group 3 } \\
\text { Ben } \\
\text { N=30 }\end{array}$ \\
\hline \hline $\begin{array}{c}\text { Pre-E2 } \\
(\mathrm{pg} / \mathrm{ml})\end{array}$ & Mean & $720.1^{\text {abc }}$ & $739.4^{\text {ade }}$ & $885.9^{\text {bdf }}$ & $669.0^{\text {cef }}$ \\
\cline { 2 - 6 } & SE & 70.5 & 43.5 & 171.2 & 60.7 \\
\hline \hline $\begin{array}{c}\text { Post-E2 } \\
(\mathrm{pg} / \mathrm{ml})\end{array}$ & Mean & $785.8^{\text {abc }}$ & $789.3^{\text {adg }}$ & $1188.6^{\text {eth }}$ & $808.5^{\text {cgl }}$ \\
\cline { 2 - 6 } & SE & 130.8 & 120.2 & 197.3 & 93.4 \\
\hline
\end{tabular}

The results show significant decreased in levels of vitamin $\mathrm{E} \quad(\mathrm{p}<0.05)$ in benign, malignant and radiotherapic groups comparing to the control group. The mean value $\pm \mathrm{SE}$ of vitamin Ein sera of control, benign, radiotherapy and malignant breast cancer were respectively as shown in Table (6).

Table (6)

Vitamin $E$ ( $\mu g \backslash d l)$ in control, benign, malignant and radiotherapy groups

\begin{tabular}{|c|c|c|c|c|c|}
\hline \multirow{2}{*}{\multicolumn{2}{|c|}{ Parameters }} & \multicolumn{4}{|c|}{ Groups } \\
\hline & & \multirow{2}{*}{$\begin{array}{c}\text { Cont } \\
N=30\end{array}$} & \multirow{2}{*}{$\begin{array}{c}\text { Group } 1 \\
\text { Rad } \\
N=20 \\
492.5^{\text {aef }} \\
\end{array}$} & \multirow{2}{*}{$\begin{array}{c}\begin{array}{c}\text { Group } 2 \\
\text { Mal } \\
N=30\end{array} \\
484.1^{\text {beg }}\end{array}$} & \multirow{2}{*}{$\begin{array}{c}\text { Group } 3 \\
\text { Ben } \\
N=30 \\
385.9^{\mathrm{dfg}}\end{array}$} \\
\hline Vitamin E & Mean & & & & \\
\hline$(\mu \mathrm{g} \backslash \mathrm{dl})$ & SE & 46.9 & 32.5 & 34.7 & 35.7 \\
\hline
\end{tabular}


Antioxidant nutrients like vitamin $\mathrm{E}$ protect cell constituents from the damaging effects of free radicals that, if unchecked, might contribute to evolution of cancer stage, unfortunately, human trials and surveys that have at tempted to link vitamin $\mathrm{E}$ intake with cancer found that vitamin $\mathrm{E}$ is not beneficial in most cases[27]

Although some research[28] links higher ingestion of vitamin $\mathrm{E}$ with decreased incidence of breast cancer, an screening of the impact of dietary agent, include vitamin $\mathrm{E}$, on the incidence from post-menopausal breast cancer in 18,000 women found not interest of the vitamin evidence to date is insufficient to supported taking vitamin $\mathrm{E}$ to prohibit cancer Patient compliance with Vitamin E for radiotherapy induced breast fibrosis appears to be worst, in clinical practice compared with previously reported randomized trials Nausea was the most commonly There are studies [29] that do not agree with us where there was a decrease in vitamin $\mathrm{E}$ in the use of radiation therapy There are studies [30] showing the reduction of vitamin $\mathrm{E}$ in bone marrow and breast cancer during radiation therapy

\section{Conclusion}

The estimation of serum MDA, estrogen, vitamin $\mathrm{E}$ and $\mathrm{BMI}$ in the present study serve as good markers to assess the severity and prognosis from breast cancer The present study also suggests an improved antioxidant system of the body either by dietary intake of natural antioxidants or by oral antioxidant supplementation to combat the generated free radicals in the body may help to reduce toxicity of radiotherapy

\section{Acknowledgment}

Praise be to god who never leaves me alone, I expresse my gratitude to my supervisor assistant Professor Dr Amer Hassan Abdallah, Dr Najwa Shehab Ahmed (Co advisor) and Dr Wafaa Raji Mohammed I want to thank the dean of college of science My wonderful family all my love father and mother and respect to them, thanks for everything

\section{References}

[1] Maryam K, Arjmandi A, Dariush M, Azadeh S, "Pre and post radiotherapy serum oxidant/antioxidant status in breast cancer patients", Impact of age, BMI and clinical stage of the disease, May-Jun, 21(3), 141148, 2016.

[2] SteroidJ, "The role of estrogen in the initiation of breastcancer", Biochem Mol Biol, Dec, 102(1-5), 89-96, 2006.

[3] Acevedo C, Amaya C, López-Guerra J, "L Rare breast tumors: review of the literature", Rep Pract Oncol Radiother, 19, 267-274, 2014.

[4] Marín A, Martín M, Liñán O, "Bystander effects and radiotherapy", Rep Pract Oncol Radiother 20:12-21, 2015.

[5] Seifried H E, Anderson D E, Fisher E I, Milner J, "A review of the interaction among dietary antioxidants and reactive oxygen species", Nutr Biochem, 18, 567579, 2007.

[6] Borek C, "Antioxidants and radiation therapy", J Nutr, 134, 3207S-3209S, 2004.

[7] Lobo V, Patil A, Phatak A, and Chandraharmacogn N, "Free radicals, antioxidants and functional foods", Impact on human health, Jul-Dec, 4(8):118126 doi: 10 4103/0973-7847, 70902, 2010.

[8] Traber MG, Shils ME, Shike M, Ross AC, Caballero B, Cousins R, "In Vitamin E Modern Nutrition in Health and Disease", Lippincott Williams \& Wilkins 10th ed Baltimore, 396-411, 2006.

[9] Washington, DC, "Food and Nutrition Board Dietary Reference Intakes: Vitamin C, Vitamin E, Selenium, and Carotenoids", Institute of Medicine, National Academy Press, 2000.

[10] Zhang Y, Chen SY, Hsu T, Santella RM, "Immunohisto chemical detection of malondialdehyde-DNA adducts in humanoral mucosa cells", Carcinogenesis.

[11] Javier C, Ana F, and Elsa V, "Obesity and Prognostic Variables in Colombian Breast Cancer Patients", A Cross-Sectional Study, 2010.

[12] Buege, J A, Aust, S D, "Microsomal lipid, Peroxidation Methods in Enzymology", In: Flesicher, S, Packer, L (Eds ), Academic Press, New-York, 52, 302, 1978. 
[13] Whitney E, and Rolfes S, "In Understanding Nutrition, $10^{\text {th }}$ ed, Thomson Learning Inc, wads worth,: 262-263, 2005.

[14] Tietz N, "Clinical Guide to Laboratory Tests, $3^{\text {rd }}$ ed Philadelphia", WA Saunders Co, 22-23, 1995.

[15] George E, "Simultaneous Determination of Retinol and $\alpha$-Tocopherol in Serum or Plasmaby Liquid Chromatography", CLIN CHEM, 29(4):708-712, 1983.

[16] Sandahl H, Theodore M, Brasky RE, "The association of the C-reactive protein inflammatory biomarker with breast cancer, incidence and mortality in the Women's Health Initiative", 10 1158/1055-9965, EPI-16-1005, Published January 2017.

[17] Arakaki M, Tamaki K, Kamada Y, Uehara $\mathrm{K}$ and Gushikawa H, "Thefeasibility of nurse intervention to improve and maintain the BMI of breast cancer survivors over 25 to appropriatelevels", SABCS, 16-P5-13-18 Published February 2017.

[18] Lorincz AM, Sukumar S, "Molecular links between obesity and breast cancer," Endocr Relat, Cancer, 13, (2), 279-292, 2006.

[19] Lahmann PH et al, "Body size and breast cancer risk: Findings from the European Prospective Investigation into Cancer and Nutrition (EPIC)", Int J Cancer, 111, (5), 762-771, 2004.

[20] Chole RH, Patil RN, Basak A, Palandurkar K, and Bhowate R, "Estimation of serum malondialdehyde in oral cancer and precancer and its association with healthy individuals, gender, alcohol, and tobacco abuse", J Cancer Res Ther, 6, no 4, pp 487-491, 2010.

[21] Ahmed Khan S, Assistant Professor, "Antioxidants and Lipid Peroxidation Status In Women with Breast Cancer", 14, (1), 71-75, 2015.

[22] Gönenç A, Ozkan Y, Torun M, and Simşek B, "Plasma malondialdehyde (MDA) levels in breast and lung cancer patients". J Clin Pharm Ther, 26, (2), 1414, 2001.

[23] Del Rio D, Stewart AJ, and Pellegrini N, "A review of recent studies on malondialdehyde as toxic molecule and biological marker of oxidative stress", Nutr
Metab, Cardiovasc, Dis, 15 (4), pp 316328, 2005.

[24] Rohaizak M, Zulkifli SZ, a Siti-Aishah $\mathrm{M}$, Nor-Aini $\mathrm{U}$, and $\mathrm{H}$ Sharifah-NoorAkmal S, "Serum sex hormone levels in pre- and postmenopausal breast cancer patients", Singapore Med J, 50, (5), 513518, 2009.

[25] Essam A, Madya B, Ezz El-Din H, Ramadanb and Alaa A, "Sex steroid hormones in serum and tissue of benign and malignant breast tumor patients", (Disease Markers) 16(3,4),151-157, 2000.

[26] Joanne DF, Frank Stanczyk Z, Lisa Kahle L, Louise Brinton A, "Prospective casecontrol study of premenopausal serum estradiol and testosterone levels and breast cancer risk", (Breast Cancer Research), 12:R98, 2010.

[27] Joshi YB, Practico D, "Vitamin E in aging, dementia, and Alzheimer's disease", Biofactors, 38(2), 90-7, 2012.

[28] Klein EA, Thompson Jr, Tangen CM, Crowley JJ, Lucia MS, Goodman PJ, et al, "Vitamin E and the risk of prostate cancer: the Selenium and Vitamin E Cancer Prevention Trial" (SELECT), JAMA; 306:1549-1556, 2011.

[29] Lee M et al, "Vitamin E in the Primary Prevention of Cardiovascular Disease and Cancer", 2215, 2006.

[30] Famoso JM, Gonzalez VJ, and McBride A, "Pentoxifylline and vitamin E therapy compliance in patients with breast fibrosis following adjuvant radiotherapy", P1-10-15 Published February 2017. 